DOI: $10.1515 / \mathrm{rrlm}-2016-0025$

\title{
Abnormal lipid metabolism in metabolic syndrome: an epigenetic perspective
}

\author{
Anomaliile metabolismului lipidic în sindromul metabolic: \\ o perspectivă epigenetică
}

\author{
Ioana Brudașcă*, Mircea Cucuianu \\ University of Medicine and Pharmacy Iuliu Hațieganu Cluj Napoca, Romania
}

\begin{abstract}
Metabolic syndrome is a complex pathology including central obesity, impaired glucose tolerance/diabetes, an atherogenic dyslipidemia and a prothrombotic state.

A new perspective on understanding the mechanisms underlying metabolic syndrome is provided by the epigenetic changes (mainly DNA methylation and histone covalent modifications), which influence gene expression without changing of the DNA sequence.

DNA methylation (mainly in carnitine palmitoyltransferase 1 A gene) and histone modifications were shown to be associated with VLDL and LDL phenotypes, with hyperglycemia and reduced level of HDL cholesterol, with hypertriglyceridemic waist phenotype and with progression of atherosclerotic occlusion in peripheral arteries.

The epigenetic changes can occur in the prenatal period, throughout the life span, and can be transmitted to the offspring. Both poor maternal nutrition and maternal obesity, diabetes and overfeeding can result in epigenetic alterations that amplify the risk of metabolic syndrome for the offspring.

Throughout life span, environmental factors, such as nutrition and exercise can induce epigenetic changes influencing the evolution of the metabolic syndrome (through adipocyte metabolism and insulin signaling pathway).

The epigenetic modifications are not completely erased during gametogenesis and embryogensis, resulting in a transgenerational transmission of an epigenetic state up to the fifth generation.

Epigenetic mechanisms are an interface between environmental stimuli and resulting phenotype by inducing a certain transcriptional state, which may be also transmitted to the next generation(s) and which may predispose to an increased risk for developing metabolic syndrome in the context of a mismatched environment.

Elucidating epigenetic modulation might provide additional information about risk evaluation and more targeted therapeutical intervention.
\end{abstract}

Keywords: metabolic syndrome, epigenetics, dyslipidemia.

\section{Rezumat}

Sindromul metabolic reprezintă o patologie complexă, care asociază obezitate abdominală, tulburări de glicoreglare/diabet zaharat, dislipidemie aterogenă şi o stare protrombotică.

O nouă perspectivă în înțelegerea mecanismelor de producere a sindromului metabolic este oferită de modificările

* Corresponding author: Ioana Brudașcă, Molecular Sciences- Medical Biochemistry, University of Medicine and Pharmacy Iuliu Hațieganu Cluj Napoca, Romania, e-mail: ioana.brudasca@yahoo.com 
epigenetice (în principal metilări ale ADN și modificări covalente ale histonelor), care influențează expresia genelor, neînsoțită de modificări în secvența ADN.

Statusul metilării ADN (în special a genei carnitin palmitoil transferazei 1A) și modificările histonelor au fost asociate cu fenotipurile subclaselor de lipoproteine VLDL și LDL, cu hiperglicemia și nivelul redus de HDL colesterol, cu fenotipul de talie hipertrigliceridemică și cu progresia leziunilor aterosclerotice în arterele periferice.

Atât subnutriția cât și obezitatea, diabetul și excesul caloric al mamei în timpul sarcinii pot produce modificări epigenetice care amplifică riscul de sindrom metabolic la urmași. In decursul vieții, factorii de mediu cum sunt nutriția și exercițiul fizic pot induce modificări epigenetice influențând evoluția sindromului metabolic (prin intermediul metabolismului adipocitelor și căii de semnalizare a insulinei). Modificările epigenetice nu dispar complet în cursul gametogenezei și embriogenezei, permițând transmiterea statusului epigenetic până la a cincea generație. Modificările epigenetice se pot produce atât prenatal, cât și de-a lungul întregii vieți, putând $f i$ transmise și la urmași. Mecanismele epigenetice sunt o interfață între stimulii de mediu şi fenotip, prin inducerea unei stări transcripționale, care se poate transmite și la generația următoare și care poate predispune la un risc crescut de a dezvolta sindrom metabolic în contextul anumitor factori de mediu nefavorabili. Elucidarea mecanismelor epigenetice poate furniza informații suplimentare despre evaluarea riscului și introducerea de terapii țintite.

Cuvinte cheie: sindrom metabolic, epigenetică, dislipidemie.

Received: 19 $9^{\text {th }}$ February 2016; Accepted: 12 th June 2016; Published: $12^{\text {th }}$ June 2016.

Metabolic syndrome represents a complex pathology, which includes central obesity, impaired glucose tolerance, atherogenic hyperlipidemia and hypertension. Other features associated with metabolic syndrome are proinflammatory state, oxidative stress, endothelial dysfunction, nonalcoholic fatty liver disease, microalbuminuria, polycystic ovarian syndrome, and hemostatic imbalance, resulting in a prothrombotic tendency.

Genome-Wide Association Studies (GWAS) have suggested that the inherited variance in an individuals'risk of developing metabolic syndrome traits cannot be explained only by the variation in the primary sequence of the genome, and that epigenetic changes occurring in the prenatal and postnatal period may intervene in the pathophysiology of metabolic syndrome, and may partially explain the "missing heritability" (1).

Epigenetics refers to changes in gene expression without changing of the DNA sequence. This approach was born on the grounds that all tissues contain the same genes, but their expression, the "phenotype" is different at a given stage in a given tissue. The explanation is that owing to epigenetic patterns, genes may be expressed at various extent, or silenced (permanently or transiently). These changes are mediated by DNA methylation of cytosine residues within cytosine-guanine dinucleotides ( $\mathrm{CpG}$ islands), covalent histone modifications (methylation, acetylation, phosphorylation, ubiquitination), micro RNAs and polycomb group proteins, resulting in alterations of the chromatin structure and function, which promotes or inhibit gene transcription $(2,3)$.

\section{Influence of epigenetics changes on lipid metabolism in metabolic syndrome}

Patients with metabolic syndrome display a particular lipid profile characterized by hypertriglyceridemia, low HDL cholesterol, predominance of atherogenic small LDL particles and high levels of apoB (4). In subjects with central obesity, the enhanced release of free fatty acids (FFA) from the enlarged intraabdominal adipose tissue leads to an increased level of free fatty acids in the portal flow, which in its turn acts on the liver, stimulating the synthesis of VLDL, thus contributing to hyperlipidemia (5). 
The role of epigenetic factors in the establishment of the lipid profile is stressed by a study showing that methylation of carnitine palmitoyltransferase 1A (CPT1A) gene is associated with VLDL and LDL phenotypes (6). CPT1A is expressed in the liver and attaches carnitine to long-chain fatty acids, thus facilitating their transport to mitochondria for $\beta$-oxidation. Hence, increased expression of CPT1A should be associated with a more protective lipid profile, through an increase in the transport of triglycerides. Increased methylation at two CpGs located in the $5^{\prime}$ untranslated region regulatory region of CPT1A was correlated with a decrease in large and medium VLDL particles, and thus a decrease in the overall number of VLDL particles. The association of methylation status at one of these CpGs with a decrease in the small subfraction of LDL led to an association with an increase in average LDL diameter. These results suggest that an increase in methylation of CPT1A is associated with a favorable lipid pattern (6).

Mendelson et al in a study on obese children demonstrated an association between differential methylation of CPT1A and triglycerides, suggesting that alterations in DNA methylation may favor the development of obesity - related dyslipidemia (7).

An important component of the metabolic syndrome is central obesity. The hypertriglyceridemic waist (HTGW) phenotype, defined as high waist circumference $(\geq 95 \mathrm{~cm}$ in males and $\geq 80 \mathrm{~cm}$ in females) combined with increased serum triglyceride concentration $(\geq 2.0 \mathrm{mmol} / \mathrm{L}$ in males and $\geq 1.5 \mathrm{mmol} / \mathrm{L}$ in females) is considered a marker of type 2 diabetes and cardiovascular disease. This phenotype shows association with DNA methylation within CPT1A (gene involved in fatty acid and triglyceride metabolism) and ABCG1 (gene encoding for ATP-binding cassette sub-family $G$ member 1 , involved in cholesterol efflux) (8).
In obese subjects with metabolic syndrome under energy restriction, reduction in body weight, total fat mass, android fat mass, total cholesterol and triglycerides were associated with higher DNA methylation levels in the transcriptional regulatory region of SERPINE1 gene, which codes for PAI-1 (9), a potent antifibrinolytic mechanism, suggesting the complex influence of epigenetic changes not only on lipid pattern but also on the hemostatic balance.

In a population-based study, exploring the associations between components of the metabolic syndrome (fasting glucose, high-density lipoprotein cholesterol, triglycerides, blood pressure, waist circumference) and global leukocyte DNA methylation, it was shown that DNA hypomethylation is independently associated with hyperglycemia and reduced level of high-density lipoprotein cholesterol, both essential components of the metabolic syndrome (10).

The effect of risk factors such as high cholesterol and homocysteine levels on atherogenesis is well documented at cellular level (on endothelial cells, monocytes/macrophages, smooth muscular cells), but the studies of their molecular effects on histones and DNA provide a deeper insight of these mechanisms. In an in-vivo model using 20week old female apo $\mathrm{E}^{+/}$mouse offspring from apo $\mathrm{E}^{-/-}$and wild-type mothers, it was shown that both prenatal induced and diet-induced hypercholesterolemia influenced histone methylation and lysine methyltransferase expression in vasculature. Moreover, these epigenetic modifications were different in endothelial cells and smooth muscle cells, suggesting the existence of a cell -specific responsiveness to a similar stimulating factor $(11,12)$.

Hyperhomocysteinemia has been associated with a global reduction in genomic DNA methylation, as well as with a downregulation of the intracellular S-adenosyl methionine (SAM)/S-adenosylhomocysteine (SAH) ratio, which is a marker of the methylation status of the cell (13). 
The progression of atherosclerotic occlusion in peripheral arteries resulting in ischaemic injury seems also to be influenced by epigenetic factors, such as DNA hypermethylation and histone modifications. The expression of oxidized low-density lipoprotein regulated pro-inflammatory gene within endothelial cells is controlled by phosphorylation/acetylation of histone $\mathrm{H} 3$ and acetylation of histone H4 (14).

Environmental exposures inducing epigenetic changes can occur during intrauterine life, throughout lifespan, and the modifications can be transmitted to the next generations.

\section{Metabolic syndrome and prenatal epige- netic factors}

During periods of tissue development, as DNA is replicating at an accelerated rate, the genome is very sensitive to epigenetic intervention (15). Several lines of evidence support the hypothesis that individuals with metabolic syndrome were prone to an incorrect "epigenetic priming"during fetal or postnatal development because of metabolic disturbances and inappropriate maternal nutrition $(16,17)$.

Children exposed to prenatal famine have increased risk of type 2 diabetes, hypertension and other cardiovascular disease (18). Maternal protein restriction has been shown to cause hypomethylation of key metabolic transcriptional regulators such as the glucocorticoid receptor, peroxisome proliferator activated receptor $\alpha$ $(\operatorname{PPAR} \alpha)$, and of the promoter of insulin receptor gene (16).

Histone hyperacetylation in the promoters of metabolic regulatory gene PGC- $1 \alpha$, and lipid metabolism intermediate transporter gene, CPT1A were reported in rat offspring exposed to uteroplacental insufficiency during gestation (19).

Because of developmental plasticity, not only poor maternal nutrition but also maternal obesity, diabetes and overfeeding can result in epigenetic alterations that amplify the risk of metabolic syndrome for the offspring (20). Rat offspring of mothers on a high fat diet during gestational period had elevated liver triglycerides and an approximately $50 \%$ reduction in insulin receptor $\beta$ at 3 months of life (21).

Animal studies had shown that fetal $\mathrm{CpG}$ dinucleotides within promoters of hypothalamic genes involved in body weight and food intake regulation are vulnerable to methylation in overweight/diabetic overfed pregnant rat females. The hypercaloric/hyperglycemic gestational milieu induces alterations in the methylation pattern, which result in changes in gene transcription, and ultimately in an increased risk of developing obesity and metabolic syndrome for the offspring (22).

An increased incidence of type 1 and 2 diabetes was reported in offspring of women with gestational diabetes or type 1 diabetes (23).

These data suggest that epigenetic mechanisms are an interface between nutritional stimuli during development and resulting phenotype.

\section{Metabolic syndrome and postnatal epige- netic factors}

Epigenetic changes are not restricted to the gestational period but can occur in response a multitude of environmental factors throughout life; also, they and are not necessarily permanent modifications $(24,25)$.

The risk of type 2 diabetes was 1.3 to 1.6 higher in women exposed during their childhood to the Dutch Famine Winter 1944-1945, comparatively to unexposed women (26).

A key element involved in type 2 diabetes pathogenesis is peroxisome proliferator activated receptor- $\gamma$ (PPAR $\gamma)$ co-activator- $1 \alpha$ (PGC- $1 \alpha)$, which was identified as a candidate for epigenetic intervention in pancreatic islets of humans with type 2 diabetes (27) and in the liver of patients of non-alcoholic fatty liver disease $(15,28)$. 
The importance of the impact of environmental factors on metabolic syndrome is stressed by observations showing that exercise induces a decrease in DNA methylation of genes involved in retinol metabolism, calcium signaling pathways and with known functions in muscle biology and type 2 diabetes (29).

A study performed on human adipose tissue demonstrated genome wide changes in DNA methylation in response to exercise, potentially influencing adipocyte metabolism (30).

The age-related increase in the prevalence of chronic disorders, including metabolic syndrome may be partially attributed to the accumulation of age-dependent methylation changes found in different tissues (31).

It is well known that the prevalence of obesity, type 2 diabetes and cardiovascular disease tend to increase with ageing. This phenomenon might be explained by the dynamics of epigenetic changes throughout life span resulting in progressive, cumulative deleterious effects of various genes. This hypothesis is supported by the observation that within families at high risk for expressing metabolic syndrome traits, there are age-associated genomic loci densely situated near genes that function in the hedgehog signaling and the maturity-onset diabetes of the young pathways (32).

A study demonstrating an inverse correlation between PAI-1 expression in human atherosclerotic plaques and the aortas of old mice and SIRT1, a class III histone deacetylase, suggested that SIRT1-mediated epigenetic inhibition of PAI-1 expression exerts a protective effect in vascular endothelial senescence (33).

\section{Metabolic syndrome and transgenera- tional epigenetic transmission}

The epigenetic modifications are not completely erased during gametogenesis and embryogensis, resulting in a transgenerational transmission of an epigenetic state up to the fifth generation $(34,35)$. The genetic predisposition for developing obesity was progressively exacerbated when the A(vy) allele of obese Agouti [A(vy)] mouse was passed along successive generations (36).

In humans, paternal pre-conceptual obesity was associated with hypomethylation of the imprinted Insulin-like Growth Factor 2 (IGF2) gene in newborns (37). A study in rats showed that female offspring of high-fat fed overweight fathers developed an early onset of impaired insulin secretion and glucose tolerance that worsened with time compared to controls (38).

\section{Conclusions}

Metabolic syndrome is a multifactorial disorder, involving complex interactions among the genetic background and environmental factors, mediated through epigenetic processes. Epigenetic mechanisms include a network of regulatory proteins acting on genes and inducing a certain transcriptional state, which may be also transmitted to the next generation(s) and may predispose to an increased risk for developing metabolic syndrome in the context of a mismatched environment.

Elucidating epigenetic modulation through studies combining animal models with human sample, as well as populational studies, might provide valuable additional information about risk evaluation and more targeted therapeutical intervention.

\section{Conflicts of interest}

The authors declare that they have no conflict of interest.
Abbreviations
Apo B - apoprotein B
CpG - cytosine-guanine dinucleotide
CPT1A - carnitine palmitoyltransferase 1A 


$\begin{array}{ll}\text { DNA } & \text { - deoxyribonucleic acid } \\ \text { FFA } & \text { - free fatty acids } \\ \text { GWAS } & \text { - Genome-Wide Association } \\ & \text { Studies } \\ \text { HDL } & \text { - High Density Lipoproteins } \\ \text { HTGW } & \text { - hypertriglyceridemic waist } \\ \text { IGF2 } & \text { - Insulin-like Growth Factor } 2 \\ \text { LDL } & \text { - Low Density Lipoproteins } \\ \text { PAI-1 } & \text { - Plasminogen Activator Inhibitor 1 } \\ \text { PGC-1 } \alpha & \text { - peroxisome proliferator activat- } \\ & \text { ed receptor- } \gamma \text { co-activator-1 } \alpha \\ \text { PPAR } \alpha & \text { - peroxisome proliferator activat- } \\ & \text { ed receptor } \alpha \\ \text { RNA } & \text { - ribonucleic acid } \\ \text { SAH } & - \text { S-adenosylhomocysteine } \\ \text { SAM } & - \text { S- adenosylmethionine } \\ \text { SERPINE1 } & \text { - Serin Protease Inhibitor 1 } \\ \text { SIRT1 } & - \text { Sirtuin 1 } \\ \text { VLDL } & - \text { Very Low Density Lipoproteins }\end{array}$

\section{References}

1. Kraja AT, Vaidya D, Pankow JS, Goodarzi MO, Assimes TL, Kullo IJ, et al. A bivariate genome-wide approach to metabolic syndrome: STAMPEED consortium. Diabetes. 2011;60:1329-39. DOI: 10.2337/db10-1011.

2. Bruce KD, Hanson MA. The developmental origins, mechanisms, and implications of metabolic syndrome. J Nutr. 2010;140(3):648-52. DOI: 10.3945/ jn.109.111179.

3. Laker RC, Wlodek ME, Connelly JJ, Yan Z. Epigenetic origins of metabolic disease: The impact of the maternal condition to the offspring epigenome and later health consequences. Food Science and Human Wellness. 2013;2(1):1-11. DOI: 10.1016/j.fshw.2013.03.002.

4. Ginsberg HN, Stalenhoef AFH. The metabolic syndrome: targeting dyslipidaemia to reduce coronary risk. J Cardiovasc Risk. 2003; 10(2):1218. DOI: $10.1177 / 174182670301000207$ DOI: 10.1097/00043798-200304000-00007.

5. Brudaşcă I, Cucuianu M. Pathogenic role of abnormal fatty acids and adipokines in the portal flow. Relevance for the metabolic syndrome, hepatic steatosis and steatohepatitis. Rom J Int Med. 2007;45:149-57.
6. Frazier-Wood AC, Aslibekyan S, Absher DM, Hopkins PH, Sha J, Tsai MY, et al. Methylation at CPT1A locus is associated with lipoprotein subfraction profiles. J Lipid Res. 2014;55(7):1324-30. DOI: 10.1194/j1r. M048504.

7. Mendelson M, Liang L, Chen J, Baccarelli A, Hirschhorn JN, S.K. Osganian SK, de Ferranti SD. Epigenetic modifications associated with dyslipidemia among obese children and adolescents. CJC. 2014;30(10):S190-1.

8. Mamtani M, Kulkarni H, Dyer T, Göring HH, Neary JL, Cole SA, et al. Genome- and epigenome-wide association study of hypertriglyceridemic waist in Mexican American families. Clin Epigenetics. 2016 Jan 20;8:6. DOI: $10.1186 / \mathrm{s} 13148-016-0173-\mathrm{x}$.

9. Lopez-Legarrea P, Mansego ML, Angeles Zulet M. SERPINE1, PAI-1 protein coding gene, methylation levels and epigenetic relationships with adiposity changes in obese subjects with metabolic syndrome features under dietary restriction. J Clin Biochem Nutr. 2013;53(3):139-44. DOI: 10.3164/jcbn.13-54.

10. Luttmer R, Spijkerman AM, Kok RM, Jakobs C, Blom HJ, Serne EH, Dekker JM. Metabolic syndrome components are associated with DNA hypomethylation. Obes Res Clin Pract. 2013 Mar-Apr;7(2):e106-e115. DOI: 10.1016/j.orcp.2012.06.001.

11. Alkemade FE, van Vliet P, Henneman P, van Dijk KW, Hierck BP, van Munsteren JC, et al. Prenatal exposure to apoE deficiency and postnatal hypercholesterolemia are associated with altered cell-specific lysine methyltransferase and histone methylation patterns in the vasculature. Am J Pathol. 2010 Feb; 176(2): 542-8. DOI: 10.2353/ajpath.2010.090031.

12. Fernandez AZ, Siebel AL, El-Osta A. Atherogenic factors and their epigenetic Relationships. Int J Vasc Med. 2010; 2010:437809. DOI: 10.1155/2010/437809.

13. Yideng J, Jianzhong Z, Ying H, Juan S, Jinge Z, Shenglan W, et al. Homocysteine-mediated expression of SAHH, DNMTs, MBD2, and DNA hypomethylation potential pathogenic mechanism in VSMCs. DNA and Cell Biology, 2007;26(8):603-11. DOI: 10.1089/ dna.2007.0584.

14. Krishna SM, Trollope AF, Golledge J. The relevance of epigenetics to occlusive cerebral and peripheral arterial disease. Clin Sci. 2015;128(9)537-58. DOI: 10.1042/ CS20140491. 
15. Laker RC, Wlodek ME, Connelly JJ, Yan Z. Epigenetic origins of metabolic disease: The impact of the maternal condition to the offspring epigenome and later health consequences. Food Science and Human Wellness. 2013;2(1):1-11. DOI: 10.1016/j.fshw.2013.03.002.

16. Burdge GC, Slater-Jefferies J, Torrens C, Phillips ES, Hanson MA, Lillycrop KA. Dietary protein restriction of pregnant rats in the $\mathrm{F} 0$ generation induces altered 1 methylation of hepatic gene promoters in the adult male offspring in the F1 and F2 generations. Br J Nutr. 2007;97:435-9. DOI: 10.1017/S0007114507352392.

17. Hass BS, Hart RW, Lu MH, Lyn-Cook BD. Effects of caloric restriction in animals on cellular function, oncogene expression, and DNA methylation in vitro. Mutat Res. 1993;295:281-9. DOI: 10.1016/09218734(93)90026-Y.

18. Godfrey KM, Sheppard A, Gluckman PD, Lillycrop KA, Burdge GC, McLean C, et al. Epigenetic gene promoter methylation at birth is associated with child's later adiposity. Diabetes. 2011;60:1528-34. DOI: 10.2337/db10-0979.

19. Fu Q, McKnight R A, Yu X, Wang L, Callaway C W, Lane R H. Uteroplacental insufficiency induces site specific changes in histone $\mathrm{H} 3$ covalent modifications and affects DNA-histone $\mathrm{H} 3$ positioning in day 0 IUGR rat liver. Physiol Genomics. 2004;20:108-16. DOI: 10.1152/physiolgenomics.00175.2004.

20. Bruce KD, Cagampang FR. Epigenetic priming of the metabolic syndrome. Toxicol Mech Method. 2011;21(4):353-61. DOI: 10.3109/ 15376516.2011.559370.

21. Buckley AJ, Keserü, B, Briody J. Thompson M, Ozanne SE, Thompson CH. Altered body composition and metabolism in the male offspring of high fat-fed rats. Metabolism. 2005;54:500-7. DOI: 10.1016/j.metabol.2004.11.003.

22. Plagemann A, Harder T, Brunn M, Harder A, Roepke $\mathrm{K}$, Wittrock-Staar $\mathrm{M}$ et al. Hypothalamic proopiomelanocortin promoter methylation becomes altered by early overfeeding: an epigenetic model of obesity and the metabolic syndrome. J Physiol 2009; 587(Pt 20):4963-76. DOI: 10.1113/jphysiol.2009.176156.

23. Clausen TD, Mathiesen ER, Hansen T, Pedersen O, Jensen DM, Lauenborg J, et al. Overweight and the metabolic syndrome in adult offspring of women with diet-treated gestational diabetes mellitus or type 1 diabetes. J Clin Endocrinol Metab. 2009;94:2464-70. DOI: $10.1210 /$ jc.2009-0305.
24. Reik W. Stability and flexibility of epigenetic gene regulation in mammalian development. Nature. 2007;447:425-32. DOI: 10.1038/nature05918.

25. Bhutani N, Burns DM, Blau HM. DNA demethylation dynamics. Cell. 2011;146:866-72. DOI: 10.1016/j. cell.2011.08.042.

26. van Abeelen AF, Elias SG, Bossuyt PM, Grobbee DE, van der Schouw YT, Roseboom TJ, et al. Famine exposure in the young and the risk of type 2 diabetes in adulthood. Diabetes. 2012; 61:2255-60. DOI: 10.2337/ db11-1559.

27. Barrès R, Osler ME, Yan J, Runne A, Fritz T, Caidahl K. Non-CpG methylation of the PGC- 1 alpha promoter through DNMT3B controls mitochondrial density. Cell Metab. 2009;10:189-98. DOI: 10.1016/j. cmet.2009.07.011.

28. Sookoian S, Rosselli MS, Gemma C, Burgue-o AL, Fernández Gianotti T, Casta-o GO, Pirola CJ. Epigenetic regulation of insulin resistance in nonalcoholic fatty liver disease: impact of liver methylation of the peroxisome proliferator-activated receptor $\gamma$ coactivator $1 \alpha$ promoter. Hepatology. 2010; 52: 1992-2000. DOI: $10.1002 /$ hep.23927.

29. 29. Nitert MD, Dayeh T, Volkov P, Elgzyri T, Hall E, Nilsson E, et al. Impact of an exercise intervention on DNA methylation in skeletal muscle from first-degree relatives of patients with type 2 diabetes. Diabetes. 2012;61: 3322-32. DOI: 10.2337/db111653.

30. Rönn T, Volkov P, Davegårdh C, Dayeh T, Hall E, Olsson $\mathrm{AH}$, et al. A six months exercise intervention influences the genome-wide DNA methylation pattern in human adipose tissue. PLoS Genet. 2013;9(6):e1003572. DOI: 10.1371/journal.pgen.1003572.

31. van Otterdijk SD, Mathers JC, Strathdee G. Do age-related changes in DNA methylation play a role in the development of age-related diseases? Biochem Soc Trans. 2013;41:803-7. DOI: 10.1042/BST20120358.

32. Zhang Y, Cerjak D, Ali O. Finding Epigenetic determinants of the metabolic syndrome. Austin J Endocrinol Diabetes. 2014;1(6):1029.

33. Wan YZ, Gao P, Zhou S, Zhang ZQ, Hao DL, Lian LS et al. SIRT1-mediated epigenetic downregulation of plasminogen activator inhibitor-1 prevents vascular endothelial replicative senescence. Aging Cell. 2014;13(5):890-9. DOI: 10.1111/acel.12247. 
34. Painter RC, Osmond C, Gluckman P, Hanson M, Phillips DI, Roseboom TJ. Transgenerational effects of prenatal exposure to the Dutch famine on neonatal adiposity and health in later life. BJOG. 2008;115:1243-9. DOI: $10.1111 /$ j.1471-0528.2008.01822.x.

35. Anway MD, Cupp AS, Uzumcu M, Skinner MK. Epigenetic transgenerational actions of endocrine disruptors and male fertility. Science. 2005;308:1466-9. DOI: $10.1126 /$ science. 1108190.

36. Waterland RA, Travisano M, Tahiliani KG, Rached MT, Mirza S. Methyl donor supplementation prevents transgenerational amplification of obesity. Int J Obes. 2008;32:1373-9. DOI: 10.1038/ijo.2008.100.
37. Soubry A, Hoyo C, Jirtle RL, Murphy SK. A paternal environmental legacy: evidence for epigenetic inheritance through the male germ line. Bioessays. 2014; 36:359-71. DOI: 10.1002/bies.201300113.

38. Ng SF, Lin RC, Laybutt DR, Barres R, Owens JA, Morris MJ. Chronic high-fat diet in fathers programs $\beta$-cell dysfunction in female rat offspring. Nature. 2010 Oct 21;467(7318):963-6. DOI: 10.1038/nature09491. 